\title{
Fish Scales as a Biosorbent of Pollutants from Wastewaters and Natural Waters (a Literature Review)
}

\author{
Ildar G. Shaikhiev ${ }^{1 \mathbb{D}}$, Natalia V. Kraysman ${ }^{2, *}{ }^{\mathbb{D}}$, Svetlana V. Sverguzova ${ }^{3 \mathbb{D}}$, Svetlana E. Spesivtseva ${ }^{4}$ \\ (i), Angela N. Yarothckina 5 (D) \\ 1 Department of Engineering Ecology, Institute of Chemical Engineering and Technology, Kazan National Research \\ Technological University, Kazan, Russian Federation \\ 2 Department of Foreign Languages for Professional Communication, Institute of Innovation Management, Kazan National \\ Research Technological University, Kazan, Russian Federation \\ 3 Department of Industrial Ecology, Institute of Chemical Engineering and Technology, Belgorod State Technological \\ University named after V.G. Shukhov, Belgorod, Russian Federation \\ 4 Department of Industrial Ecology, Institute of Chemical Engineering and Technology, Belgorod State Technological \\ University named after V.G. Shukhov, Belgorod, Russian Federation \\ 5 KSPOAU "Kamchatka Polytechnic College", Petropavlovsk-Kamchatsky, Russian Federation \\ * Correspondence: n_kraysman@mail.ru;
}

Scopus Author ID 56114338900

Received: 26.04.2020; Revised: 23.05.2020; Accepted: 25.05.2020; Published: 1.06.2020

\begin{abstract}
We have reviewed literature data on the use of various fish scales as a sorption material for extracting various pollutants (heavy metal ions, dyes, antibiotics) from waste and natural waters. The parameters of sorption interaction that ensure the greatest degree of pollutant removal are given in this paper. It is shown that the sorption capacity of fish scales can be increased by modifying various chemical reagents. The isotherms of pollutant adsorption with fish scales were found to be, in most cases, most adequately described by the Langmuir model, less often by the Freundlich model, and the pseudo-second second-order model most often describes the process kinetics.
\end{abstract}

Keywords: fish scales; metal ions; dyes; antibiotics; adsorption; models of adsorption isotherms; thermodynamic parameters.

(C) 2020 by the authors. This article is an open-access article distributed under the terms and conditions of the Creative Commons Attribution (CC BY) license (https://creativecommons.org/licenses/by/4.0/).

\section{Introduction}

In the last few decades, the world scientific community has been intensively studying industrial and agricultural waste as reagents for removal of pollutants of different nature from natural and wastewaters with a particular focus on ligno-and cellulose-containing waste from the processing of agricultural raw materials and wood biomass [1-10]. The latter are mainly used as sorption materials in native or modified form to adsorb pollutants of different origin from aqueous media (heavy metal ions, oil and petrochemical products, dyes, surfactants, pesticides, etc.).

Among the various biosorbents, chitin is the second most abundant natural biopolymer after cellulose. However, chitosan, with its molecular structure similar to cellulose, is more critical than chitin. Chitin and chitosan have also been extensively investigated as sorption materials for the extraction of various pollutants from aqueous media [11-14].

It should be noted that among natural biopolymers, a large share is taken by keratin in terms of content in the biosphere, which is part of the family of fibrillar proteins with mechanical strength, which among biological materials comes second only to chitin. Basically, 
keratins build the horny derivatives of the epidermis - such structures as hair, nails, horns, animal hooves, birds' feathers, as well as scales of fish and reptiles [15].

The elemental composition of keratin is as follows, \%: $\mathrm{C}-50.3-52.5 ; \mathrm{H}-6.4-7.3 ; \mathrm{N}-$ 16.2-17.7; $\mathrm{O}-15.0-20.7 ; \mathrm{S}-0.7-5.0$. The simplest formula corresponding to the elemental composition of keratin contains 39 carbon atoms (C39H65N11SO13). Keratin consists of 20 amino acids, 17 of which have the highest content: alanine, arginine, aspartic acid, valine, histidine, glycine, glutamic acid, isoleucine, leucine, lysine, methionine, proline, serine, threonine, tyrosine, cystine, and phenylalanine. Their amount varies widely in the macromolecule of keratin. The structure, composition, and structure of keratin are detailed in this paper [16].

It is shown that wool and wool waste effectively extract various pollutants from aqueous media $[17,18]$. Keratin is also the building material of birds' feathers, which are studied as effective sorption materials for removal of metal ions, dyes, and petroleum products from natural and wastewaters $[19,20]$.

\section{Fish Scales Structure and Composition}

Fish scales are also a multi-tonnage fish processing waste. Information about the morphology, properties, and structure of fish scales on the example of arapaima scales are given in the review [21]. In fish, there are three main types of scales, which differ both in form and in material from which they are built: plakoid, ganoid, and bony. Bony scales are characteristic of most modern bony fish, phylogenetically is a modification of the ganoid scales. There are two types of bony scales: the cycloid scales with smooth hind edge and the ctenoid characterized by small teeth on their posterior margins (cteni). The cycloid scales [22] are characteristic mainly of lower fish (herring-, pike-like, etc.); the ctenoid scales can be found in highly organized fishes (perch-like, flatfishes). The size of the scales is closely related to the way the fish moves. The largest scales are found in slow-moving fish, most of which live in still waters (many carps). It was established that the scales structure is clearly divided into the thin outer highly mineralized hyalodentin layer and a thick internal basal plate [22]. The hyalodentin layer structure consists of pigments, hydroxyapatite crystals, and randomly oriented collagen fibers. The base plate of scales consists of a set of thin lamellae, each including densely packed bundles of collagen fibers of constant diameter. In such a way, collagen fibers are distributed in the base plate of scales like overlaid plywood. The collagen fiber bundles are packed quite densely. Scales' resistance to mechanical stress is very high due to this hierarchically organized structure. Fish scales are a source of protein (40-60\%) and minerals (30-56\%). Scales collagen accounts for $80-90 \%$ of all their proteins.

The review [23] indicates that fish scales make up 1 to $10 \%$ of the fish mass, and they are mainly used to produce fish meal (about $10 \%$ of all fish scales). It is shown that the best way to use fish scales is direct use as food or indirect use for the production of feed additives. The paper also describes some other ways of using fish scales: in various composite materials, as the main raw material for guanine production, an organic compound which is one of the purine bases (2-amino-hypoxanthine), for fish glue production due to the high collagen content, use in cosmetic, medical, pharmaceutical industry and, in functional foods production.

In medicine, fish collagen is used as various films, sponges, threads, bandages, patches, contact lenses, gels, ointments; preparations for the treatment of wounds, burns, trophic ulcers, pulpitis, hypertension, osteoarthritis, urorrhea; capsules and tablets with various fillers for oral administration; as culture media, a substitute for skin and bone tissue; as a component of 
artificial blood vessels, an implant in cosmetic surgery; it was found to have an anti-cancer effect [23].

\section{Metal Ions Extraction Using Fish Scales}

Fish scales can be used as a sorption material for removal of pollutants from aquatic environments. In the world literature, there is information about the use of fish scales for the removal of metal ions from natural and wastewater [24-53]. Further, metal ions are listed in alphabetical order to simplify the description of the material.

Studies were made on adsorption of $\mathrm{As}(\mathrm{V})$ ions by carp scales (Cyprinus carpio) [25]. It was determined that the scales' surface area is $18.5 \mathrm{~m}^{2} / \mathrm{g}$, pore volume $0.356 \mathrm{~cm}^{3} / \mathrm{g}$, the average pore diameter $26.7 \mathrm{~nm}$. It was determined that the maximum sorption capacities determined by the Langmuir model were $\mathrm{q}_{\max }=28.8-32.1 \mathrm{mg} / \mathrm{g}$ at temperatures of $20-40^{\circ} \mathrm{C}$. Sorption isotherms at these temperatures are most adequately described by the Langmuir model $\left(\mathrm{R}^{2}=0.984-0.992\right)$. The thermodynamic parameters of the process were as follows: $\Delta \mathrm{G}^{\mathrm{o}}=-40.3$, -42.2 and $-44.2 \mathrm{~kJ} / \mathrm{mol}$ at 293,303 , and $313 \mathrm{~K}$, respectively, $\Delta H o=17.6 \mathrm{~kJ} / \mathrm{mol}$, $\Delta \mathrm{So}=197 \mathrm{~J} / \mathrm{mol} \cdot \mathrm{K}$.

To increase the sorption capacity for arsenic ions, carp scales were modified by nanoparticles of $\mathrm{Ce}_{2} \mathrm{O}_{3}$. It was determined that the maximum sorption capacity at $\mathrm{pH}=4-6$ was $78 \mathrm{mg} / \mathrm{g}$ at the initial concentration of ions $\mathrm{As}(\mathrm{V}) \mathrm{C}_{\mathrm{o}}=5.78 \mathrm{mg} / \mathrm{dm}^{3}$, the adsorption isotherm is well described by the Freundlich model (R2=0.998) [26].

Studies were made on adsorption of As(III) and As(V) ions by cod scales (Gadus Morhua) under static conditions. The highest values of sorption capacity determined using the Langmuir equation were found to be achieved at $\mathrm{pH}=4$ and are equal to $\mathrm{q}_{\max }=26.67 \mathrm{mg} / \mathrm{g}$ and $24.75 \mathrm{mg} / \mathrm{g}$ for $\mathrm{As}(\mathrm{V})$ and $\mathrm{As}(\mathrm{III})$ ions, respectively [27]. The adsorption isotherms of these ions were determined to be most adequately described by the Langmuir model.

Studies were also made on adsorption of As(III) and As(V) ions by cod scales (Gadus Morhua) under dynamic conditions. For this purpose, simulated solutions containing As(III) and $\mathrm{As}(\mathrm{V})$ ions with an initial concentration of the last $0.45-84 \mathrm{mg} / \mathrm{dm}^{3}$ with different $\mathrm{pH}$ values were passed through a cod scale layer weighing $61.54 \mathrm{~g}$ at a rate of $2.0-2.75 \mathrm{~cm}^{3} / \mathrm{min}$. The characteristics at which the pollutants break through the layer of sorption material were determined by simulating the experiment using a two-dimensional mass transfer model. It was determined that such parameters as the porosity of the sorption material, selectivity, flow rate, and adsorption coefficient make a significant contribution to the change in the time intervals of the breakthrough [28]. It is indicated that such indicators as $\mathrm{pH}$ of the aqueous phase, the dosage of the adsorbent, also have a significant effect on the breakthrough. It was concluded that the said pollutants were extracted due to the physical adsorption and complexation with functional groups that are part of the biopolymers of the scales [29].

Carp scales (Cyprinus carpio) were also used for adsorption of $\mathrm{Cd}^{2+}$ ions under static conditions [25]. It was determined that the maximum sorption capacities determined by the Langmuir model were $\mathrm{q}_{\max }=64.4-69.0 \mathrm{mg} / \mathrm{g}$ at temperatures of $20-40^{\circ} \mathrm{C}$. Sorption isotherms at these temperatures are most adequately described by the Langmuir model $\left(R^{2}=0.992-0.996\right)$,

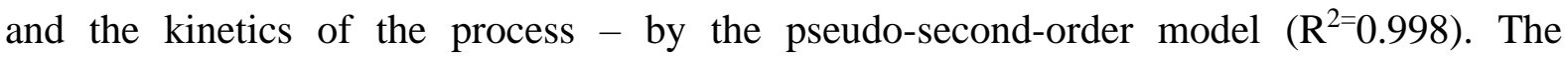
thermodynamic parameters of the process were as follows: $\Delta \mathrm{G}^{\mathrm{o}}=-40.7,-42.7$ and $-44.7 \mathrm{~kJ} / \mathrm{mol}$ at 293,303 , and $313 \mathrm{~K}$, respectively, $\Delta \mathrm{H}^{\mathrm{o}}=18.5 \mathrm{~kJ} / \mathrm{mol}, \Delta \mathrm{S}^{\mathrm{o}}=202 \mathrm{~J} / \mathrm{mol} \cdot \mathrm{K}$.

Studies were also made on adsorption of $\mathrm{Cd}^{2+}$ ions by glutaraldehyde cross-linked croaker (Micropogonias furnieri) scales collagen using IR spectroscopy, electron microscopy, 
DSC and TGA, etc. It was determined that at the initial concentration of $\mathrm{CD}^{2+}$ ions $3.67 \cdot 10^{-}$ ${ }^{4} \mathrm{~mol} / \mathrm{dm}^{3}$ in the solution, the maximum sorption capacity is $2.22 \cdot 10^{-5} \mathrm{~mol} / \mathrm{dm}^{3}$. It is determined that the adsorption kinetics is regulated by the pseudo-second-order model. $\Delta \mathrm{H}^{\mathrm{o}}$ values range from -12.55 to $-117.0 \mathrm{~kJ} / \mathrm{mol}$, depending on the initial concentration of cadmium ions and the solution temperature [30].

Studies were made on $\mathrm{Co}^{2+}$ and $\mathrm{Pb}^{2+}$ ions adsorption by cod (Gadus Morhua) and spangled emperor (Lethrinus nebulosus) scales in dynamic conditions [31]. The initial $\mathrm{Co}^{2+}$ ions concentrations were 50 and $100 \mathrm{ppm}, \mathrm{Pb}^{2+}$ ions - 470, and $1000 \mathrm{ppm}$. The experiments determined that the increase in the flow rate through the layer of sorption material results in an earlier breakthrough of pollutants into the filtrate. It was also found that the concentration of metal cations did not have a dominant effect on metal ions breakthrough. Sorption materials porosity was found to have a significant effect on sorption characteristics.

There are several reports on the study of adsorption of $\mathrm{Cr}^{+}$ions by scales of different fish species [32-35]. In particular, the paper [31] considers adsorption of the said ions using Catla fish (Catla catla) scales under static conditions. It is found that the highest sorption capacity $\mathrm{q}_{\max }=27.18 \mathrm{mg} / \mathrm{g}$ is achieved under the following conditions: $\mathrm{C}_{0}=15 \mathrm{mg} / \mathrm{dm}^{3}, \mathrm{pH}=1.0$, scales dosage $=0.05 \mathrm{~g} / \mathrm{dm}^{3}$, mixing rate $=200 \mathrm{rpm}$. It is found that the sorption equilibrium is achieved within $180 \mathrm{~min}$. It was determined that the adsorption isotherms are most adequately described by the Freundlich model, and the process kinetics is regulated by the pseudo-secondorder model. The thermodynamic parameters of the process were as follows: $\Delta \mathrm{G}^{\mathrm{o}}=-13.62$, 15.95 and $-17.58 \mathrm{~kJ} / \mathrm{mol}$ at 293,313 and $333 \mathrm{~K}$ respectively, $\Delta \mathrm{H}^{\circ}=15.10 \mathrm{~kJ} / \mathrm{mol}, \Delta \mathrm{S}^{\circ}=98 \mathrm{~J} / \mathrm{mol} \cdot \mathrm{K}$ [33]. It is indicated that the process is endothermic and occurs spontaneously; it is a chemisorption process.

Thermodynamic and calorimetric parameters of $\mathrm{Cr}^{6+}$ ions adsorption by croaker scales (Micropogonias furnieri) at $25^{\circ} \mathrm{C}$ were studied. It was found that enthalpies of $\mathrm{Cr}^{6+}$ ions sorption on croaker scales are highly exothermic (from -226.43 to $-183.79 \mathrm{~kJ} / \mathrm{mol}$ ) and the interaction energies decrease with increasing concentration of $\mathrm{Cr}(\mathrm{VI})$ ions in the solution. The solution microcalorimetry made us assume that interactions of scales with chromium ions occurs mainly due to the reaction of electrostatic interaction on the surface of the sorption material between positively charged collagen scales and negatively charged chromate ions [34].

Studies were made on adsorption of $\mathrm{Cr}^{6+}$ ions by glutaraldehyde cross-linked croaker (Micropogonias furnieri) scales collagen. It was determined that the maximum sorption capacity of the sorption material is $39.9 \mathrm{mg} / \mathrm{g}$ for $\mathrm{Cr}^{6+}$ ions. $\mathrm{Cr}(\mathrm{VI})$ ions sorption by cross-linked croaker scales increases with increasing the initial pollutant concentration in the solution and decreases with increasing the solution temperature. Kinetic studies have shown that a multilinear exponential model is most suitable for describing the adsorption process. The values of the constant of $\mathrm{Cr}^{6+}$ ions diffusion to the sorption material increase, both with increasing the temperature and with the initial concentration of $\mathrm{Cr}(\mathrm{VI})$ ions in the solution [35].

Studies were made on $\mathrm{Cu}^{2+}$ ions adsorption by Nile tilapia (Tilapia nilotica Linnaeus) scales under static conditions [36]. The experiments were carried out at different ratios of biosorbent and copper ions at $\mathrm{pH}=4.05$ with varying contact time ( $\mathrm{t}=$ from $45 \mathrm{~min}$ to 8 days) and dosage of scales ( $\mathrm{M}=$ from 0.2 to $7 \mathrm{~g}$ ). It is found that increasing the ratio scales: $\mathrm{Cu}^{2+}$ ions and contact time ensures the highest degree of sorbate extraction $(97.18 \%$ at a biosorbent content of $5 \mathrm{~g}$ and its ratio to $\mathrm{Cu}^{2+}$ ions=10: 1 for 8 days) [36]. It was determined that the 
isotherm of $\mathrm{Cu}^{2+}$ ions adsorption by Nile tilapia scales is most adequately described by the Langmuir model, and the kinetics of the process is subject to the pseudo-first-order model [37].

The scales of common bass (Dicentrarchus labrax) were also used as a biosorbent to extract $\mathrm{Cu}^{2+}$ ions from simulated solutions [38]. It was found that at the initial concentration of $\mathrm{Cu}^{2+}$ ions $=200 \mathrm{mg} / \mathrm{dm}^{3}$ and $\mathrm{pH}=3.0, \mathrm{~T}=45^{\circ} \mathrm{C}$ and a scales dosage of $1 \mathrm{~g} / \mathrm{dm}^{3}$, the maximum sorption capacity is $127.16 \mathrm{mg} / \mathrm{g}$. It is stated that the adsorption isotherm is most adequately described by the Langmuir model $\left(\mathrm{R}^{2}=0.9932\right)$, and the adsorption kinetics is best regulated by the pseudo-second-order model [38].

The paper [39] considers the adsorption of $\mathrm{Cu}^{2+}$ ions using Catla fish (Catla catla) scales under static conditions. It is found that the highest sorption capacity $\mathrm{q}_{\max }=79.35 \mathrm{mg} / \mathrm{g}$ is achieved under the following conditions: $\mathrm{C}_{0}=50 \mathrm{mg} / \mathrm{dm}^{3}, \mathrm{pH}=5.5$, scales dosage $=10 \mathrm{~g} / \mathrm{dm}^{3}$, mixing rate $=1500 \mathrm{rpm}$. It is found that the sorption equilibrium is achieved within $180 \mathrm{~min}$. It was determined that the adsorption isotherms are most adequately described by the Langmuir model, and the process kinetics is regulated by the pseudo-second-order model [39].

Studies were made on $\mathrm{La}^{3+}$ ions adsorption with unknown fish species scales used as biosorbent. It is noted that the maximum absorption of $\mathrm{La}(\mathrm{III})$ ions equal to $200.0 \mathrm{mg} / \mathrm{g}$ occurs under the following conditions: $\mathrm{pH}=6.0$, scales dosage $=0.3 \mathrm{~g} / \mathrm{dm}^{3}$, initial concentration of metal ion $=300 \mathrm{mg} / \mathrm{dm}^{3}, \mathrm{~T}=50^{\circ} \mathrm{C}, \mathrm{t}=4 \mathrm{~h}$. It was determined that the adsorption isotherm is more adequately described by the Langmuir model, and the adsorption kinetics is more accurately described by the pseudo-second-order model. The thermodynamic parameters of the process were as follows: $\Delta \mathrm{G}^{\mathrm{o}}=-24.17,-24.55$ and $-24.93 \mathrm{~kJ} / \mathrm{mol}$ at 293,303 and $313 \mathrm{~K}$, respectively, $\Delta \mathrm{H}^{\mathrm{o}}=13.04 \mathrm{~kJ} / \mathrm{mol}, \Delta \mathrm{S}^{\mathrm{o}}=38 \mathrm{~J} / \mathrm{mol} \cdot \mathrm{K}[40]$, indicates that the process is endothermic and spontaneous. FTIR analysis confirmed the participation of different functional groups in the composition of scale biopolymers in the chemisorption of $\mathrm{La}$ (III) ions.

$\mathrm{Ni}^{2+}$ ions were studied during adsorption under static conditions using tilapia (Oreochromis niloticus) scales as the sorption material. At the initial $\mathrm{Ni}^{2+}$ ions concentration $=20 \mathrm{ppm}, \mathrm{pH}=9$, the scales dosage $=2 \mathrm{~g} / \mathrm{dm}^{3}$, mixing rate $=125 \mathrm{rpm}$ for 4 hours, the said ions removal degree amounted to $74.6 \%$. The maximum sorption capacity under the above conditions was $1.49 \mathrm{mg} / \mathrm{g}$ [41].

Studies were made on $\mathrm{Pb}^{2+}$ ions adsorption by crushed Rohu (Labeo rohita) scales under static conditions. It was determined that the scales' surface area was $76.32 \mathrm{~m}^{2} / \mathrm{g}$, and the maximum sorption capacity reached $196 \mathrm{mg} / \mathrm{g}$ at $\mathrm{pH}=3.5, \mathrm{~T}=20^{\circ} \mathrm{C}$, mixing speed $200 \mathrm{rpm}$ for 24 hours. The adsorption isotherm is most accurately described by the Freundlich model $\left(\mathrm{R}^{2}=0.9447\right)$, and the adsorption kinetics is regulated by the pseudo-second-order model $\left(\mathrm{R}^{2}=1.0\right)$ [42]. It is shown that the scale biomass pretreatment using autoclaving, boiling, heating, treatment with $\mathrm{HCl}, \mathrm{H}_{3} \mathrm{PO}_{4}$, and $\mathrm{Ca}(\mathrm{OH})_{2}$ solutions resulted in an increase in sorption indices, while exposure to $\mathrm{H}_{2} \mathrm{SO}_{4}, \mathrm{NaOH}$, and $\mathrm{Al}(\mathrm{OH})_{3}$ solutions showed the reverse pattern.

Studies were also made on the influence of arsenic ions presence on $\mathrm{Pb}^{2+}$ ions adsorption by cod (Gadus Morhua) scales [43]. Initial concentrations of $\mathrm{Pb}^{2+}$ ions were $2.5,10$ and $40 \mathrm{mg} / \mathrm{dm}^{3}, \mathrm{AS}^{3+}$ and $\mathrm{As}^{5+}-350$ and $1000 \mu \mathrm{g} / \mathrm{dm}^{3}$. The experiments were carried out at different $\mathrm{pH}$ values. It was found that with an increase in arsenic ion concentration, the sorption capacity of cod scales for $\mathrm{Pb}^{2+}$ ions increases, and the greatest extraction of the said ion is observed at $\mathrm{pH}=11$ [43].

The scales of Nile tilapia (Oreochromis niloticus) were studied for $\mathrm{Se}^{4+}$ ions adsorption under static conditions. It was determined that the highest sorption capacity was observed at $\mathrm{pH}=3-6$ and increases with increasing the initial ion concentration and contact time. It is found 
that the maximum sorption capacity of tilapia scales is low and equals to $2.12 \mathrm{mg} / \mathrm{g}$. The adsorption isotherm is more adequately described by the Freundlich model $\left(\mathrm{R}^{2}=0.913\right)$. The kinetics of the process is more accurately regulated by the intraparticle diffusion model [44].

Studies were made on the ability of Nile tilapia (Oreochromis niloticus) scales as a biosorbent to remove $\mathrm{Zn}^{2+}$ ions from wastewater of the automotive industry. The maximum sorption capacity is $16.92 \mathrm{mg} / \mathrm{g}$, and the adsorption isotherm is well described by the Langmuir model and the process kinetics by the Elovich model [45].

The sorption characteristics for $\mathrm{Zn}^{2+}$ ions were compared to those for $\mathrm{Fe}^{3+}$ ions in adsorption by Mozambique tilapia (Oreochromis mossambicus) scales. Table 1 shows the conditions under which the maximum values of the sorption capacity for these metal ions and the conditions of the process are achieved [46]. It was determined that the scale adsorption isotherms for $\mathrm{Zn}^{2+}$ and $\mathrm{Fe}^{3+}$ ions are most accurately described by the Langmuir model, and the process kinetics is more adequately described by the pseudo-second-order model $\left(\mathrm{R}^{2}=0.999\right.$ and $\mathrm{R}^{2}=0.998$, respectively) [47]. IR spectroscopy showed chemisorption of these metal ions with functional biopolymer groups that are part of the scales.

Table 1. Results on ions sorption of $\mathrm{Zn}^{2+}$ and $\mathrm{Fe}^{3+}$ in the found optimal conditions [46].

\begin{tabular}{c|c|c|c|c|c|c}
\hline Ion & $\mathrm{pH}$ & $\begin{array}{c}\text { Dosage } \\
\text { of } \\
\text { scale, } \mathrm{g}\end{array}$ & $\begin{array}{c}\text { Touch } \\
\text { time, } \\
\mathrm{h} .\end{array}$ & $\begin{array}{c}\text { The initial } \\
\text { concentration } \\
\text { of metal ions }\end{array}$ & $\begin{array}{c}\text { Process } \\
\text { efficiency }\end{array}$ & $\begin{array}{c}\text { Sorption } \\
\text { capacity, } \\
\mathrm{mg} / \mathrm{g}\end{array}$ \\
\hline $\mathrm{Zn}^{2+}$ & 6.0 & 0.02 & 3 & 10.0 & 93.52 & 46.76 \\
\hline $\mathrm{Fe}^{3+}$ & 4.5 & 0.8 & 3 & 300.0 & 65.9 & 15.2 \\
\hline
\end{tabular}

The sorption indices in adsorption of $\mathrm{Zn}^{2+}$ ions were compared to those for $\mathrm{Pb}^{2+}$ ions by Mozambique tilapia scales [48]. It was found that the highest sorption capacity for $\mathrm{Pb}^{2+}$ ions equal to $26.9 \mathrm{mg} / \mathrm{g}$ is achieved at $\mathrm{pH}=5.5$, the sorption material dosage $=0.001 \mathrm{~g}$, and the initial metal ion concentration $=0.3 \mathrm{mg} / \mathrm{g}$ [49].

The paper considers the removal of the above-mentioned metal ions $\left(\mathrm{Fe}^{3+}, \mathrm{Pb}^{2+}, \mathrm{Zn}^{2+}\right)$ by Nile tilapia (Oreochromis niloticus) scales from wastewater [50]. IR spectroscopy, scanning electron microscopy, $\mathrm{x}$-ray diffraction analysis showed chemisorption [51].

The scales of this fish were also used for adsorption of $\mathrm{Cu}^{2+}, \mathrm{Fe}^{3+}$, and $\mathrm{Mn}^{4+}$ ions from the Owabi and the Wewe (Ghana) rivers. The study determined that the sorption capacity for $\mathrm{Cu}$, $\mathrm{Mn}, \mathrm{Fe}$ ions adsorbed from the Owabi river was 685.70 $\pm 16.51,247.06 \pm 50.46$ and $892.90 \pm$ 96.29 , respectively; from the Wewe river, it was $501.60 \pm 77.78,300.89 \pm 54.61$ and $413.04 \pm$ $9.92 \mathrm{mg} / \mathrm{kg}$, respectively [52].

Studies were made on adsorption of 4 heavy metal ions $\left(\mathrm{Cu}^{2+}, \mathrm{Pb}^{2+}, \mathrm{Co}^{2+}, \mathrm{Ni}^{2+}\right)$ by Nile tilapia (Oreochromis niloticus) scales. The highest sorption capacity was found for $\mathrm{Cu}^{2+}$ ions$58 \mathrm{mg} / \mathrm{g}$ [53], and the sorption characteristics of metal ions are arranged in a row: $\mathrm{Cu}^{2+}>\mathrm{Pb}^{2+}$ $>\mathrm{Co}^{2+}>\mathrm{Ni}^{2+}$. Low-vacuum scanning electron microscopy and elemental analysis show that the ion exchange reaction is the main mechanism of metal ions adsorption by fish scales.

In addition to metal cations, Catla fish (Catla catla) scales were used to extract fluoride ions. It was determined that at the initial concentration of fluoride ions in a solution, equal to $8.5 \mathrm{mg} / \mathrm{dm}^{3}$, the highest sorption indices $(17.84 \mathrm{mg} / \mathrm{g})$ were achieved at $\mathrm{pH}=9.93$, sorption material dosage $=22.6 \mathrm{~g} / \mathrm{dm}^{3}$, and sorbate contact time $=179.7 \mathrm{~min}$ [54]. It was determined that the adsorption isotherms at different temperatures are more adequately described by the Langmuir model, and the process kinetics is regulated by the pseudo-second-order model. 


\section{Fish Scales as a Dye Sorption Material}

In addition to heavy metal ions, studies were made on adsorption of various dyes by scales of various fish species [55-70]. In particular, these included adsorption of Remazol yellow, Remazol blue, and Remazol red by striped leporinus (Leporinus elongates) scales. It was determined that the maximum sorption capacity for these dyes is low and at $30^{\circ} \mathrm{C}$ equals to $3.10 ; 5.19$ and $5.41 \mathrm{mg} / \mathrm{g}$, respectively. The thermodynamic parameters of the process were as follows: the $\Delta$ Ho values range from 83.3 to $199.7 \mathrm{~kJ} / \mathrm{mol}, \Delta$ Go from 17.9 to $22.5 \mathrm{~kJ} / \mathrm{mol}, \Delta$ So from 219.2 to $599.4 \mathrm{~J} / \mathrm{mol} \cdot \mathrm{K}[55]$.

Studies were made on adsorption of acid blue 121 dye by common bass (Dicentrarchus labrax) [56] scales and determined the optimal process conditions: $\mathrm{pH}=2$, temperature $=30^{\circ} \mathrm{C}$, initial dye concentration $-300 \mathrm{mg} / \mathrm{dm} 3$ and the scales dosage of $=1 \mathrm{~g} / \mathrm{dm} 3$. The maximum sorption capacity determined by the Langmuir equation was $300.7 \mathrm{mg} / \mathrm{g}$. Based on the thermodynamic process parameters, the adsorption process was concluded to be spontaneous and exothermic [56, 57].

The above sorption material was studied to remove acid blue 324 dye. The experiments were carried out under the conditions given above, except that the initial dye concentration was $200 \mathrm{mg} / \mathrm{dm} 3$. It was determined that the value of the maximum sorption capacity at $25^{\circ} \mathrm{C}$, determined by the Langmuir model, was $192 \mathrm{mg} / \mathrm{g}$ [58]. The thermodynamic parameters of the process were as follows: $\Delta \mathrm{Go}=-7.49,-5.27$ and $-4.25 \mathrm{~kJ} / \mathrm{mol}$ at 298,303 and $313 \mathrm{~K}$, respectively, $\Delta \mathrm{Ho}=-55.5 \mathrm{~kJ} / \mathrm{mol}, \Delta \mathrm{So}=-161.9 \mathrm{~J} / \mathrm{mol} \cdot \mathrm{K}$, indicating that the process occurs due to external as well as intraparticle diffusion [58].

The scales of common bass (Dicentrarchus labrax) were also used to extract Methylene blue dye. The experiments were carried out at an initial dye concentration of 0.5 and $5.0 \mathrm{mmol} / \mathrm{dm} 3$ at $25-55^{\circ} \mathrm{C}$. The maximum sorption capacity was $2.1 \mathrm{mmol} / \mathrm{g}(0.672 \mathrm{mg} / \mathrm{g})$ at $35^{\circ} \mathrm{C}$. The adsorption isotherms are more accurately described by the Langmuir model [59].

A much larger sorption capacity $(68.72 \mathrm{mg} / \mathrm{g})$ was determined with Methylene blue dye adsorption by carp (Cyprinus carpio) scales, modified magnetite nanoparticles (Fe3O4). The scales were determined to have an area of $0.65 \mathrm{~m} 2 / \mathrm{g}$, after magnetite treatment $-4.62 \mathrm{~m} 2 / \mathrm{g}$. It is found that the maximum sorption capacity was $66.7 \mathrm{mg} / \mathrm{g}$. The adsorption isotherms at different temperatures are most adequately described by the Sips model and the process kinetics - by the pseudo-second-order model. The thermodynamic parameters of the process were as follows: $\Delta \mathrm{Go}=-7.3055,-6.1153$ and $-5.2634 \mathrm{~kJ} / \mathrm{mol}$ at 303,313 and $323 \mathrm{~K}$ respectively, $\Delta \mathrm{Ho}=-$ $38.299 \mathrm{~kJ} / \mathrm{mol}, \Delta \mathrm{So}=-102.462 \mathrm{~J} / \mathrm{mol} \cdot \mathrm{K}, \mathrm{E}=-0.466 \mathrm{~kJ} / \mathrm{mol}[60]$.

Carp scales have also been studied to determine the optimal medium for adsorption and desorption of Methylene orange dye. A comparative study of dye adsorption at different $\mathrm{pH}$ values shows that the equilibrium time was achieved earlier in case of a solution with a neutral $\mathrm{pH}$ value than in case of an acidic solution. At the same time, it was found that the fibers of fish scales were resistant to adsorbed dye molecules release at a lower $\mathrm{pH}$ than in a neutral medium [61].

Rohu (Labeo rohita) scales were used to remove Malachite green dye with varying parameters of the aquatic environment. It was determined that at the initial dye concentration of $50 \mathrm{mg} / \mathrm{dm} 3, \mathrm{pH}=8$, the scales dosage $=2 \mathrm{~g} / \mathrm{dm} 3, \mathrm{~T}=20-40^{\circ} \mathrm{C}$, and the contact time of $3 \mathrm{~h}$, the maximum sorption capacity determined using the Langmuir equation was $31.3-38.5 \mathrm{mg} / \mathrm{g}$. It was determined that the adsorption isotherms are regulated by the Langmuir model $(\mathrm{R} 2=0.999)$, and the process kinetics corresponds to the pseudo-second-order model [62]. 
Also, Rohu scales were studied as a sorption material for removal of Brilliant red dye under static conditions. It was found that at the initial dye concentration of $7 \cdot 10-5 \mathrm{~mol} / \mathrm{dm} 3$, the highest degree of the pollutant removal was observed at $\mathrm{pH}=7.2$ at 30 -minute contact. It was found that the adsorption isotherms at $30-50^{\circ} \mathrm{C}$ are most accurately described by the Langmuir model, and the calculated adsorption energy value equal to $-34.92 \mathrm{~kJ} / \mathrm{mol}$ indicates that the process is exothermic [63].

Nile tilapia (Oreochromis niloticus) scales were characterized as a sorption material [64] and investigated with varying process parameters in the presence of $\mathrm{NaCl}$ and surfactants to extract Reactive blue $5 \mathrm{G}$ dye from simulated solutions. It was found that the maximum sorption capacity of tilapia scales was $272.4 \mathrm{mg} / \mathrm{g}$ [65], the addition of WK Profiber PLM 28 surfactant increased the above parameter to $291 \mathrm{mg} / \mathrm{g}$, and the presence of $\mathrm{NaCl}$ in the solution - to $299 \mathrm{mg} / \mathrm{g}[66]$.

It was determined that the best conditions for Congo red adsorption with an initial concentration of $14 \mathrm{mg} / \mathrm{dm} 3$ by grass carp (Ctenopharyngodon idella) scales occurred at $\mathrm{pH}=7$ and a temperature of $25^{\circ} \mathrm{C}$, a sorption material dosage of $0.2 \mathrm{~g} / \mathrm{dm} 3 \mathrm{~cm}$. It was determined that adsorption proceeded with the endothermic effect, was spontaneous and irreversible [67].

Acid blue 113 dye adsorption by a mixture of scales of four-fingered threadfin (Eleutheronema tetradactylum), red grouper (Epinephelus moara), and black-spotted snapper (Lutjanus johnii) [68] was studied with varied process parameters: $\mathrm{T}=30-50 \mathrm{oC}, \mathrm{pH}=5-10, \mathrm{t}=10-180 \mathrm{~min}$. It is found that the maximum sorption capacity calculated according to the Langmuir equation was $151-157.3 \mathrm{mg} / \mathrm{g}$. The adsorption isotherms built at different temperatures are most adequately described by the Langmuir model and the process kinetics - by the pseudo-second-order model.

Studies were made on Indigo carmine dye adsorption by fish scales pretreated with $\mathrm{NaOH}$ solution at $\mathrm{pH}=9$ for 4 hours under dynamic conditions. The dye solution at a concentration of $10-20 \mathrm{mg} / \mathrm{dm} 3$ was passed through a column with a $3-6 \mathrm{~cm}$ layer. It was determined that depending on the conditions of the experiment; the maximum sorption capacity was $8-13 \mathrm{mg} / \mathrm{g}$. It was determined that the Adams-Bogart, Thomas, Jan, and Yun-Nelson models describe the process with low accuracy [69].

Carbonized Rohu (Labeo rohita) scales were used to remove Reactive orange 16 dye from aqueous solutions. It is shown that carbonation dramatically increases the surface area $(213 \mathrm{~m} 2 / \mathrm{g}$ by the BET method) and the total pore volume $(0.215 \mathrm{~cm} 3 / \mathrm{g})$. Studies were made on the effect of the initial dye concentration $(25-400 \mathrm{mg} / \mathrm{dm} 3)$, the solution $\mathrm{pH}(3-13)$, and the temperature $\left(30-50^{\circ} \mathrm{C}\right)$ on the adsorption efficiency of carbonized Rohu scales. It was found that the sorption capacity was $105.8,107.2$, and $114.2 \mathrm{mg} / \mathrm{g}$ at 30,40 , and $50^{\circ} \mathrm{C}$, respectively. The adsorption isotherms were best regulated by the Freundlich model and adsorption kinetics graphs - by pseudo-second-order models [70].

\section{Organic Compounds Extraction Using Fish Scales}

There are several publications devoted to the removal of organic compounds from aqueous solutions by fish scales. In particular, studies were made of tetracycline adsorption from aqueous solutions by giant gourami (Osphronemus gouramy) scales collagen. It was shown that at the initial tetracycline concentration of $236 \mu \mathrm{g} / \mathrm{cm} 3$, the lowest concentration of the latter is achieved after 1 hour of contact $-160 \mu \mathrm{g} / \mathrm{cm} 3[71]$.

Silver sea trout (Cynoscion acoupa) scales treated with glutaraldehyde and amines, was investigated for doxycycline removal from water bodies. Studies were made to determine the 
influence of various parameters on the sorption capacity, which was $3.2 \cdot 10-6 \mathrm{~mol} / \mathrm{g}$ at an initial doxycycline concentration of $2.5 \cdot 10-5 \mathrm{~mol} / \mathrm{dm} 3$. It was determined that the best results of antibiotic desorption were obtained at $\mathrm{pH}=4.0$ [72]. It is found that the process kinetics at 25$45^{\circ} \mathrm{C}$ was most adequately described by the pseudo-first-order model.

Glutaraldehyde and chitosan gel-treated croaker (Micropogonias furnieri) scales were studied for the ability to remove dichlorophenol-2,6-indophenol. The structure of the resulting material was investigated by various physical and chemical methods. It was found that the sorption energy was $1.46,3.6$, and $2.3 \mathrm{~J} / \mathrm{mol}$ at dichlorophenol-2,6-indophenol concentrations in solutions of $1 \cdot 10-5,1 \cdot 10-4$, and $1 \cdot 10-3 \mathrm{~mol} / \mathrm{dm} 3$. The $\Delta \mathrm{H}$ values ranged from -536.7 to $50.9 \mathrm{~kJ} / \mathrm{mol}$, indicating the occurrence of chemisorption interaction [73].

The crushed saddled seabream scales were used in conjunction with aluminum sulfate as a coagulant for the humic acid deposition from an aqueous solution. The optimal conditions were determined in the course of experiment planning. It was found that the highest degree of humic substances deposition at the initial concentration of the latter $=10 \mathrm{mg} / \mathrm{dm} 3$ was observed at an aluminum sulfate dosage $=1.03 \mathrm{mg} / \mathrm{dm} 3$, fish scales $=1.13 \mathrm{mg} / \mathrm{dm} 3$ at $\mathrm{pH}=5$ [74].

\section{Conclusions}

In general, we have summarized the information on the use of fish scales of different species as a sorption material for the removal of different pollutants from aquatic environments. It is shown that the sorption capacity of fish scales can be increase by modifying various chemical reagents. The isotherms of pollutant adsorption with fish scales were found to be, in most cases, most adequately described by the Langmuir model, less often by the Freundlich model, and the process kinetics is most often described by the pseudo-second-order model. Given the large volume of fish-scale formation on a global scale, we can recommend it as a promising, environmentally friendly sorption material for the removal of pollutants from natural and wastewaters.

\section{Funding}

This research received no external funding.

\section{Acknowledgments}

This research has no acknowledgment.

\section{Conflicts of Interest}

The authors declare no conflict of interest.

\section{References}

1. Mo, J.; Yang, Q.; Zhang, N.; Zhang, W.; Zheng, Y.; Zhang, Z. A review on agro-industrial waste (AIW) derived adsorbents for water and wastewater treatment. J. Environ. Manag. 2018, 227, 395-405, https://doi.org/10.1016/j.jenvman.2018.08.069.

2. Acharya, J.; Kumar, U.; Rafi, P.M. Removal of heavy metal ions from wastewater by chemically modified agricultural waste material as potential adsorbent - A review. Int. J. Current Eng. Tech. 2018, 8, 526-530, https://doi.org/10.14741/ijcet/v.8.3.6.

3. Krstić, V.; Urošević, T.; Pešovski, B. A review on adsorbents for treatment of water and wastewaters containing copper ions. Chem. Eng. Sci. 2018, 192, 273-287, https://doi.org/10.1016/j.ces.2018.07.022.

4. Kakkar, S.; Malik, A.; Gupta, S. Treatment of pulp and paper mill effluent using low cost adsorbents: An overview. J. Appl. Natur. Sci. 2018, 10, 695-704, https://doi.org/10.31018/jans.v10i2.1769. 
5. Kanthasamy, S.; Hadibarat, T.; Hidayat, T.; Alamri, S.A.; Al-Ghamdi, A.A. adsorption of azo and anthraquinone dye by using watermelon peel powder and corn peel powder: equilibrium and kinetic studies. Biointerface Res. ApChem. 2020, 10, 4706-4713, https://doi.org/10.33263/BRIAC101.706713.

6. Doshi, B.; Sillanpää, M.; Kalliola, S. A review of bio-based materials for oil spill treatment. Water Res. 2018, 135, 262-277, https://doi.org/10.1016/j.watres.2018.02.034.

7. Ahmad, T.; Danish, M. Prospects of banana waste utilization in wastewater treatment: A review. J. Environ. Manag. 2018, 206, 330-348, https://doi.org/10.1016/j.jenvman.2017.10.061.

8. Sharma, S.; Kaur, A. Various methods for removal of dyes from industrial effluents - A review. Indian J. Sci. Tech. 2018. 11, 1-21.

9. Ngwenya, S.; Guyo, U.; Zinyama, N.P.; Chigondo, F.; Nyamunda, B.C.; Muchanyereyi, N. Response surface methodology for optimization of $\mathrm{Cd}(\mathrm{II})$ adsorption from wastewaters by fabricated tartaric acid-maize tassel magnetic hybrid sorbent. Biointerface Res. ApChem. 2019, 9, 3996-4005, https://doi.org/10.33263/BRIAC94.996005.

10. Pyrzynska, K. Removal of cadmium from wastewaters with low-cost adsorbents. J. Environ. Chem. Eng. 2019, 7, https://doi.org/10.1016/j.jece.2018.11.040.

11. Bhatnagar, A.; Sillanpää, M. Applications of chitin- and chitosan-derivatives for the detoxification of water and wastewater - A short review. Adv. Colloid Interface Sci. 2009, 152, 26-38, https://doi.org/10.1016/j.cis.2009.09.003.

12. Ngah, W.S.W.; Teong, L.C.; Hanafiah, M.A.K.M. Adsorption of dyes and heavy metal ions by chitosan composites: A review. Carbohydr. Polym. 2011, 83, 1446-1456, https://doi.org/10.1016/j.carbpol.2010.11.004.

13. Vakili, M.; Rafatullah, M.; Salamatinia, B.; Abdullah, A.Z.; Ibrahim, M.H.; Tan, K.B.; Gholami, Z.; Amouzgar, Application of chitosan and its derivatives as adsorbents for dye removal from water and wastewater: A review. Carbohydr. Polym. 2014, 113, 115-130, https://doi.org/10.1016/j.carbpol.2014.07.007.

14. Zia, Q.; Tabassum, M.; Gong, H.; Li, J. A Review on chitosan for the removal of heavy metals ions. J. Fiber Bioeng. Inform. 2019, 12, 103-128.

15. https://ru.wikipedia.org/ keratins.

16. Wang, B.; Yang, W.; McKittrick, J.; Meyers, M.A. Keratin: structure, mechanical properties, occurrence in biological organisms, and efforts at bioinspiration. Progr. Mater. Sci. 2016, 76, 229-318, https://doi.org/10.1016/j.pmatsci.2015.06.001.

17. Hanzlíková, Z.; Braniša, J.; Hybler, P.; Šprinclová, I.; Jomová, K.; Porubská, M.. Sorption properties of sheep wool irradiated by accelerated electron beam. Chem. Papers 2016, 70, 1299-1308, https://doi.org/10.1515/chempap-2016-0062.

18. Braniša, J.; Jomová, K.; Kovalcíková, R.; Hybler, P.; Porubská, M. Role of post-exposure time in Co(II) sorption of higher concentrations on electron irradiated sheep wool. Molecules. 2019, 24, https://doi.org/10.3390/molecules24142639.

19. Moon, W.C.; Palaniandy, A review on interesting properties of chicken feather as low-cost adsorbent. Int. J. Integrat. Eng. 2019, 11, 136-146.

20. Olawale, S.A.; Funke, A.W.; Dede, A.H.; Hajara, Y. Biosorption of $\mathrm{Pb}(\mathrm{II})$ and $\mathrm{Cu}(\mathrm{II})$ from aqueous solution using chicken feathers: thermodynamics and mass balance studies. Asian J. Appl. Chem. Res. 2018, 1, 1-9, https://doi.org/10.9734/AJACR/2018/v1i39662.

21. Drelich, A.J.; Monteiro, S.N.; Brookins, J.; Drelich, J.W. Fish skin: A natural inspiration for innovation. Adv. Biosyst. 2018, 2, https://doi.org/10.1002/adbi.201800055.

22. Tylik, K.V. General Ichthyology: Monograph. Kaliningrad: OOO “Aksios” 2015; pp. 294 [Obshaya ikhtiologia: monografia. Kaliningrad: $O O O$ “Aksios”] (in Russian).

23. Vorobiov, V.I.; Nijnikova, E.V. Research and Application of Fish Scales in Various Industries (Review).[ Issledovanya i primenenye rybnoy tsheshui $\mathrm{v}$ razlitchnykh otroslyakh promyshlennosti (obzor).] Izvestiya KNTRU. 2017, 45, 147-159 (in Russian).

24. Kunkun, Z.; Zheng, P.; Yi, G.; Bin, L. Research progress on fish scale adsorption materials. Food Ind. Tech. 2013, 12 .

25. Bajic, Z.J.; Djokic, V.R.; Veličković, Z.S.; Vurun, M.; Ristic, M.Đ.; Issa, N.B.; Marinković, A.D. Equilibrium, kinetic and thermodynamic studies on removal of $\mathrm{Cd}(\mathrm{II}), \mathrm{Pb}(\mathrm{II})$ and $\mathrm{As}(\mathrm{V})$ from wastewater using carp (Cyprinus carpio) scales. Digest J. Nanomater. Biostruct. 2013, 8, 1581-1590.

26. Veličković, Z.S.; Bajić, Z.J.; Karkalić, R.; Karanac, M.M.; Đolić, M.B.; Marinković, A.D. New low-cost adsorbent from fish scales carp modified by nanoparticles of cerium dioxide to remove As(V) ions from water. Int. Conf. «Contaminated Sites», Banska Bystrica 2018, 196-197.

27. Rahaman, M.S.; Basu, A.; Islam, M.R. The removal of As(III) and As(V) from aqueous solutions by waste materials. Biores. Tech. 2008, 99, 2815-2823, https://doi.org/10.1016/j.biortech.2007.06.038.

28. Rahaman, M.S.; Omi, F.R.; Basu, A. Experimental and numerical modelling of arsenic adsorption in fixedbed dynamic columns packed with atlantic cod fish scales. Canadian J. Chem. Eng. 2015, 93, 2024-2030, https://doi.org/10.1002/cjce.22294. 
29. Basu, A.; Rahaman, M.S.; Islam, M.R. Extension of the pore diffusion approach for modeling binary adsorption of lead and arsenic ions in a fixed-bed column packed with atlantic cod fish scales. Canadian J. Chem. Eng. 2011, 89, 499-507, https://doi.org/10.1002/cjce.20420.

30. Silva, E.S. Escamas de piexe corvina (Micropogonias furnieri) reticuladas com glutaraldeido: estudo cinetico e termodinamico da interacaocom Cd(II) por calorimetria isotermico. Dissertacao de mestrado, Brasil, Sao Cristavao. 2012; pp. 107

31. Basu, A.; Mustafiz, S.; Islam, M.R.; Bjorndalen, N.; Rahaman, M.S.; Chaalal, O. A comprehensive approach for modeling sorption of lead and cobalt ions through fish scales as an adsorbent. Chem. Eng. Commun. 2006, 193, 580-605, https://doi.org/10.1080/00986440500193707.

32. Kondapalli, S.; Mohanty, K. Biosorption of hexavalent chromium from aqueous solutions by Catla catla scales: Equilibrium and kinetics studies. Chem. Eng. J. 2009, 155. 666-673, https://doi.org/10.1016/j.cej.2009.08.024.

33. Kondapalli, S.; Mohanty, K. Influence of temperature on equilibrium, kinetic and thermodynamic parameters of biosorption of $\mathrm{Cr}(\mathrm{VI})$ onto fish scales as suitable biosorbent. J. Water Res. Protec. 2011, 3, 429-439. https://doi.org/10.4236/jwarp.2011.36053.

34. Moura, K.O.; Vieira, E.F.S.; Cestari, A.R. The use of solution microcalorimetry to evaluate chemically modified fish scales as a viable adsorbent for heavy metals. J. Therm. Anal. Calorim. 2012, 107, 999-1005, https://doi.org/10.1007/s10973-011-1612-8.

35. Moura, K.O.; Vieira, E.F.S.; Cestari, A.R. Poly(glutaraldehyde)-stabilized fish scale fibrillar collagen-some features of a new material for heavy metal sorption. J. Appl. Polym. Sci. 2012, 124, 3208-3221, https://doi.org/10.1002/app.35398.

36. Huang, E. Use of fish scales as biosorbent for the removal of copper in water. Water Res. 2007, 30, 19851990.

37. Bazarin, G.; Módenes, A.N.; Vieira, M.G.A.; Borba, C.E.; Espinoza-Quiñones, F.R.; Scariotto, M.C. Tilapia scales: characterization and study of $\mathrm{Cu}(\mathrm{II})$ removal by ion exchange with $\mathrm{Ca}(\mathrm{II})$. Separ. Sci. Tech. 2019, 55, 186-198, https://doi.org/10.1080/01496395.2019.1577260.

38. Uzunoglu, D.; Ozer, A. Adsorption of hazardous heavy metal copper(II) from aqueous effluents onto waste material fish (Dicentrarchus labrax) scales: optimization, equilibrium, kinetics, thermodynamic, and characterization studies. Desalin. Water Treatm. 2016, 57, 22794-22798, https://doi.org/10.1080/19443994.2015.1111594.

39. Das, A.; Bhowal, A.; Datta, S. Biomass characterisation and adsorption mechanism of $\mathrm{Cu}(\mathrm{II})$ biosorption onto fish (Catla catla) scales. Int. J. Environ. Eng. 2016, 8, 81-94, https://doi.org/10.1504/IJEE.2016.078242.

40. Das, D.; Varshini, J.S.; Das, N. Recovery of lanthanum(III) from aqueous solution using biosorbents of plant and animal origin: Batch and column studies. Minerals Eng. 2014, 69, 40-56, https://doi.org/10.1016/j.mineng.2014.06.013.

41. Othman, N.; Juki, M.I. Characterization and optimization of heavy menals biosorption by fish scales. Region. SymEng. Tech., Kuching, Sarawak, Malaysia. 2011, 126-132.

42. Nadeem, R.; Ansari, T.M.; Khalid, A.M. Fourier transform infrared spectroscopic characterization and optimization of $\mathrm{Pb}(\mathrm{II})$ biosorption by fish (Labeo rohita) scales. J. Hazard. Mater. 2008, 156, 64-73, https://doi.org/10.1016/j.jhazmat.2007.11.124.

43. Basu, A.; Rahaman, M.S.; Mustafiz, S.; Islam, M.R. Batch studies of lead adsorption from a multicomponent aqueous solution onto Atlantic cod fish scale (Gadus morhua) substrate. J. Environ. Eng. Sci. 2007, 6, 455462, https://doi.org/10.1139/S06-070.

44. Kongsri, S.; Janpradit, K.; Buapa, K.; Techawongstien, S.; Chanthai, S. Nanocrystalline hydroxyapatite from fish scale waste: Preparation, characterization and application for selenium adsorption in aqueous solution. Chem. Eng. J. 2013, 215-216, 522-532. https://doi.org/10.1016/j.cej.2012.11.054.

45. Ribeiro, C.; Scheufele, F.B.; Alves, H.J.; Kroumov, A.D.; Espinoza-Quiñones, F.R.; Módenes, A.N.; Borba, C.E. Evaluation of hybrid neutralization/biosorption process for zinc ions removal from automotive battery effluent by dolomite and fish scales. Environ. Tech. 2018, 40, 2373-2388, https://doi.org/10.1080/09593330.2018.1441332.

46. Zayadi, N.; Othman, N. Removal of zinc and ferum ions using Tilapia Mossambica fish scale. Int. J. Integr. Eng. 2013, 5, 23-29.

47. Othman, N.; Abd-Kadir, A.; Zayadi, N. Waste fish scales as cost effective adsorbent in removing zinc and ferum ion in wastewater. ARPN J. Eng. Appl. Sci. 2016, 11, 1584-1592.

48. Othman, N.; Abd-Kadir, A.; Zayadi, N. Mozambique tilapia fish scales as potential biosorbent for Zn and $\mathrm{Pb}$ ions removal: kinetic and isotherm studies. 2nd IWA Malaysia Young Water Professional Conf., Kuala Lumpur, Malaysia. 2015, 14.

49. Zayadi, N.; Othman, N. Characterization and optimization of heavy metals biosorption by fish scales. $A d v$. Mater. Res. 2013, 795, 260-265, https://doi.org/10.4028/www.scientific.net/AMR.795.260.

50. Ribeiro, C.; Scheufele, F.B.; Espinoza-Quinones, F.R.; Modenes, A.N.; Vieira, M.G.A.; Kroumov, A.D.; Borba, C.E. A comprehensive evaluation of heavy metals removal from battery industry wastewaters by 
applying bioresidue, mineral and commercial adsorbent materials. J. Mater. Sci. 2018, 53, 7976-7995. https://doi.org/10.1007/s10853-018-2150-6.

51. Ribeiro, C. Estudo do potencial de remoção de metais por calcário dolomítico, escama de peixe e resina catiônica visando o tratamento da água residuária da indústria de baterias. Tese de Doutorado em Engenharia Química, Universidade Estadual do Oeste do Paraná, Toledo, PR, 2018, 124

52. Kwaansa-Ansah, E.E.; Nkrumah, D.; Nti, S.O.; Opoku, F. Adsorption of heavy metals (Cu, Mn, Fe and Ni) from surface water using Oreochromis Niloticus scales. Pollution 2019, 5, 115-122, https://doi.org/10.22059/poll.2018.259347.454.

53. Villanueva-Espinosa, J.F.; Hernández-Esparza, M.; Ruiz-Treviño, F.A. Adsorptive properties of fish scales of Oreochromis Niloticus (Mojarra Tilapia) for metallic ion removal from waste water. Ind. Eng. Chem. Res. 2001, 40, 3563-3569, https://doi.org/10.1021/ie000884v.

54. Bhaumik, R.; Mondal, N.K.; Chattoraj, S. An optimization study for defluoridation from synthetic fluoride solution using scale of Indian major carp Catla (Catla catla): An unconventional biosorbent. J. Fluorine Chem. 2017, 195, 57-69, https://doi.org/10.1016/j.jfluchem.2017.01.015.

55. Oliveira, C.S. Estudo cinetico e termodinamico da interacao de corantes anionicos com escamas do peixe Piau (Leporinus elongatus). Dissertacio mestrado de Quimica, Sao Cristavao, Universidado Federal de Sergipe, 2009, $90 \mathrm{f}$.

56. Uzunoglu, D.. Levrek baligi (Dicentrarchus labrax) pulu ve ticari hidroksiapatit ile Acid blue 121 boyarmaddesinin adsorpsiyonu. Yuksek lisans tezi, Mersin universitesi, 2014, $131 \mathrm{p}$.

57. Uzunoglu, D.; Ozer, A. Adsorption of Acid blue 121 dye on fish (Dicentrarchus labrax) scales, the extracted from fish scales and commercial hydroxyapatite equilibrium, kinetic, thermodynamic, and characterization studies. Desalin. Water Treat 2016, 57, 14109-14131, https://doi.org/10.1080/19443994.2015.1063091.

58. Kuntas, A.; Tuncay, E.; Uzunoglu, D.; Ozer, A. Acid blue 324 boyarmaddesinin levrek baligi puluna adsorpsiyonu. Anadolu Üniversitesi Bilim ve Teknoloji Dergisi A-Uygulamalı Bilimler ve Mühendislik. 2015, 16, 283-292, https://doi.org/10.18038/btd-a.25614.

59. Oliveira, I.M. Caracterizacao de escamas de peixe Robalo (Dicentrarchus labrax) e seu estudo de sorcao de corantes em meio aquoso. Dissertacio mestrado de Quimica, Sao Cristavao, Universidado Federal de Sergipe, 2011, $82 \mathrm{f}$.

60. Ahmadgurabi, N.G.; Koohi, A.D.; Pirbazari, A.E. Fabrication, characterization, regeneration and application of nanomagnetic $\mathrm{Fe}_{3} \mathrm{O}_{4} @$ fish scale as a bio-adsorbent for removal of Methylene blue. J. Water Environ. Nanotech. 2018, 3, 219-234, https://doi.org/10.22090/jwent.2018.03.003.

61. Chakraborty, J.; Dey, S.; Halder, U.C. An eco-friendly bio-sorbent derived from fish (Carp) scale: A study of commercial dye removal. Int. J. Sci. Eng. Research. 2016, 7, 72-76.

62. Chowdhury, S.; Saha, P.D.; Ghosh, U. Fish (Labeo rohita) scales as potential low-cost biosorbent for removal of malachite green from aqueous solutions. Bioremediation J. 2012, 16, 235-242, https://doi.org/10.1080/10889868.2012.731444.

63. Begum, H.A.; Kabir, M.H. Removal of brilliant red from aqueous solutions by adsorption on fish scales. Dhaka Univercity J. Sci. 2013, 61, 7-12.

64. Ribeiro, C.; Scheufele, F.B.; Espinoza-Quicones, F.R.; Módenes, A.N.; da Silva, M.G.C.; Vieira, M.G.A.; Borba, C.E. Characterization of Oreochromis niloticus fish scales and assessment of their potential on the adsorption of reactive blue 5G dye. Colloids and Surfaces A: Physicochemical and Engineering Aspects 2015, 482, 693-701, https://doi.org/10.1016/j.colsurfa.2015.05.057.

65. Neves, C.V.; Nardino, A.P.; Kerber, K.C.; Ribtiro, C.; Borba, C.E. Estudo da cinetica e do equilibrio de adsorcao do corante azul reativo $5 \mathrm{G}$ utilizando escfma de peixe como adsorvente. XXXVII ENEMP, Universidade Federal de São Carlos, Brasil. 2015, 8.

66. Neves, C.V.; Scheufele, F.B.; Nardino, A.P.; Vieira, M.G.A.; da Silva, M.G.C.; Módenes, A.N.; Borba, C.E. Phenomenological modeling of reactive dye adsorption onto fish scales surface in the presence of electrolyte and surfactant mixtures, Environ. Technol. 2018, 39, 2467-2483, https://doi.org/10.1080/09593330.2017.1356876.

67. Xiong, J.; Wang, H.; Zhang, G. Absorption ability and mechanism of fish scales from grass carp to Congo red. J. Fish. China 2012, 36, 306-313.

68. Ooi, J.; Lee, L.Y.; Hiew, B.Y.Z.; Thangalazhy-Gopakumar, S.; Lim, S.S.; Gan, S. Assessment of fish scales waste as a low cost and eco-friendly adsorbent for removal of an azo dye: Equilibrium, kinetic and thermodynamic studies. Bioresource Technol. 2017, 245, 656-664, https://doi.org/10.1016/j.biortech.2017.08.153.

69. Rocha, A.C.M.A.; Valentim, I.B.; de Abreu, F.C. Indigo carmine removal from aqueous solution using natural biopolymer: fixed-bed column study. European Int. J. Sci. Tech. 2015, 4, 16.

70. Marrakchi, F.; Ahmed, M.J.; Khanday, W.A.; Asif, M.; Hameed, B.H. Mesoporous carbonaceous material from fish scales as low-cost adsorbent for reactive orange 16 adsorption. J. Taiwan Institute Chem. Eng. 2017, 71, 47-54, https://doi.org/10.1016/j.jtice.2016.12.026.

71. Pratama, S.M.; Barqly, G.J.K.; Widyastuti, R.; Wardani, R.N.; Sielma, D.F.; Munawir, dan A. Pengaruh lama perendaman terhadap absorpsi tetrasiklin pada adsorben limbah sisik ikan gurami (Osphronemus Gouramy). Maj Ked Gi Ind. 2015, 1, 161-166, https://doi.org/10.22146/majkedgiind.9231. 
72. Lemos, J.A.S. Escamas de peixe pescada amarela (Cynoscion acoupa) modificados com glutaraldeido e aminas para remocao de doxiciclina em meio aquoso. Dissertacao (mestrado em Quimica), Universidade Federal de Sergipe, Sao Cristyvao, 2017, $87 \mathrm{f}$.

73. Mota, J.A.; Chagas, R.A.; Vieira, E.F.S.; Cestari, A.R. Synthesis and characterization of a novel fish scaleimmobilized chitosan adsorbent - preliminary features of dichlorophenol sorption by solution calorimetry. J. Hazard. Mater. 2012, 229-230, 346-353, https://doi.org/10.1016/j.jhazmat.2012.06.010.

74. Harfouchi, H.; Hank, D.; Hellal, A. Response surface methodology for the elimination of humic substances from water by coagulation using powdered Saddled sea bream scale as coagulant-aid. Proc. Safety Environ. Protec. 2016, 99, 216-226, https://doi.org/10.1016/j.psep.2015.10.019. 